\title{
Dwu(wielo)języczny teatr w zglobalizowanym kontekście brytyjskim, czyli o różnych stylach dramatu migracyjno- -transkulturowego
}

Elwira M. Grossman

TEKSTY DRUGIE 2016, NR3, S. 60-80

DOI: $10.18318 /$ td. $2016.3-4$

P rzedstawienia teatralne, które wybrałam do omówienia w niniejszym artykule, trudno jednoznacznie zaklasyfikować pod względem przynależności językowej i kulturowej. Mimo że były one wystawiane w Wielkiej Brytanii (a niektóre także w Polsce), istnieją albo w dwóch obiegach jednocześnie, albo w interkulturowej wyobrażonej przestrzeni pogranicza, która nie ma sprecyzowanej lokalizacji geograficznej. Jest to obszar pomiędzy językami, kulturami i tradycjami, który zwykłam określać jako 'przestrzeń transkulturowych idiomów'. Jest ona efektem (s)tworzenia nowej, 'trzeciej wartości' wynikającej z wymieszania szeroko pojętej kultury macierzystej (w tym przypadku polskiej) i innych kultur lokalnych w kraju docelowym².

1 Zob. E. Grossman Towards the Literature of Transcultural Idioms: Ewal Eva Stachniak and Lisa Appignanesi w: Displaced Women, ed. L. Aiello, 1. Charnley i M. Palladino, Cambridge Scholars Publishing, Newcastle upon Tyne 2014, 5. 61-69.

2 Zob. esej E. Grossman Kategoria polskości w formacie transkulturowym, w: Literatura polska w świecie, t. 4 red. R. Cudak, Gnome, Uniwersytet Śląski, Katowice 2012, s. 361-371.

Elwira M.

Grossman - dr, pracuje na Wydzıale Języków Współczesnych na Uniwersytecie w Glasgow. Kierownik Programu Literatury Porównawczej Współuczestniczka projektu Researching Multilingually. Zainteresowania: metodologia badań literackich, interkulturowość, dramat i teatr współczesny. Redaktorka I współautorka Studies in Language, Literature and Cultural Mythology in Poland. Investigating "The Other" (2002). Kontakt: elwira. grossman@glasgow. ac.uk 
Oczywiście miejsce wystawienia danego spektaklu jest zawsze określone (choć nie zawsze ograniczone do jednej lokalizacji), ale chodzi tu bardziej o wielokulturowe wyznaczniki świata scenicznego, takie jak jedno-, dwu- lub wielojęzyczność, odmienność konwencji teatralnej oraz akcent, i to rozumiany w bardzo szerokim znaczeniu tego słowa, słyszalny na scenie zarówno w mowie polskiej, jak i angielskiej, ale odnoszący się do sfery zarówno językowej, jak i emocjonalnej. Stąd tytuł mojego tekstu ${ }^{3}$.W przeciwieństwie bowiem do literatury emigracyjnej, akcent w transkulturowym teatrze (i filmie) wyznacza ich estetykę z nie mniejszą siłą przekazu niż sam język i zdecydowanie zabarwia performatywny wymiar całego spektaklu4. Do owych wyróżników estetyki emigracyjnej, idąc tropem obserwacji metodologicznych Mieke Bal, powrócę w dalszej części swojego artykułu, a tymczasem wymienię wybrane przedstawienia, które są estetycznie zróżnicowane i obrazują polską emigrację po roku $2004 \mathrm{w}$ formacie transkulturowym. Są to:

(1) The Polish Play (2008), sztuka wystawiona przez teatr objazdowy Farnham Maltings w Anglii w lutym oraz w Szkocji w kwietniu 2008 roku.

(2) Działalność grupy teatralnej polskich emigrantów, określanej jako 'teatr polsko-szkocki' o nazwie Gappad ${ }^{5}$ i działającej w Szkocji od lipca 2006 do grudnia 2012 roku. Jego założycielką była Agnieszka Bresler, a dyrektorem artystycznym od roku 2007 Robert Przekwas. W czasie swojej działalności Gappad miał sześć premier: RE-ID (2007), As YouAlways Do (2008), Hear Me (2009), Jordan (2010), Family Voices (2010) oraz Spina/Backbone (2011).

(3) Tu i Teraz ('Here and Now'), to dwujęzyczne przedstawienie oparte na sztuce, której główną treść napisała Nicola Werenowska, a wyreżyserował Sam Potter, wystawiając je w londyńskim Hampstead Theatre przez pięć kolejnych tygodni od premierowego przedstawienia 19 grudnia 2012 roku oraz

3 Ten graficzny zapis słowa zapożyczam od Edwarda Balcerzana, który odnosi je do innego kontekstu, zob. Jedno- oraz dwu(wielo) iezzyczność literackich "światów”, "Teksty Drugie" $2009 \mathrm{nr} 6$, S. 9-20.

4 O poetyce akcentu w estetyce migracyjnej pisała Mieke Bal, zob. Translating Translation "lournal of Visual Culture" 2007, vol. 6, nr 1, s. 109-124.

5 Nazwa grupy pochodzi od imion osób stanowiących pierwszy skład trupy: Gosia, Agnieszka, Pola, Piotr, Anita i Dominik.

6 Agnieszka Bresler opracowała także dwa monodramy: Starsza Pani (The Old Lady, 2010) - spektakl przygotowany we współpracy z włoską grupą Teatro La Madrugada, oraz 11/11 - 'spotkanie poetyckie' oparte na podobnych motywach, coStarsza Pani, ale wystawione po polsku w ramach obchodów rocznicy 11 listopada, w Domu im. gen. Sikorskiego w Glasgow. Przedstawienie było dramatyzowanym występem grupowym opartym na wierszach Małgorzaty Zbudniewek. 
w Southampton, w The Nuffield Theatre i The Mercury Theatre przez kilka pierwszych tygodni 2013 roku'.

(4) Bloody East Europeans, to sztuka utrzymana w konwencji między burleską a musicalem, w wykonaniu ukraińskiej grupy teatralnej Molodyi Teatr z Londynu, przedstawiona w ramach Edinburgh Festival Fringe od 25 do 29 sierpnia 2015 roku, a także w Glasgow 23 sierpnia, w kawiarence Milk Cafe. Motyw polskich emigrantów oraz języka polskiego jest tu silnie akcentowany, mimo tytułu słusznie nasuwającego dużo szersze skojarzenia: Przekleci wschodnioeuropejczycy. Scenariusz napisał Uilleam Blacker, Brytyjczyk, określający się nie bez dumy przydomkiem 'wschodnioeuropejczyka z mianowania i wyboru's.

Powyższa lista nie obejmuje wszystkich sztuk nawiązujących do tożsamościowego paradygmatu pogranicza i wystawianych w latach 2004-2015. Zarówno przedstawień, jak i grup teatralnych je prezentujących było więcej, ale wybierając powyższe przykłady kierowałam się przede wszystkim ich różnorodnością estetyczną, obecnością dwu - lub wielojęzyczności w scenariuszach i spektaklach oraz dostępnością materiałów na ich temat ${ }^{9}$. Nie ulega wątpliwości, że zróżnicowanie wszystkich wybranych przykładów wiąże się ściśle z kontekstem, w którym powstały, ale są oglądane przez widzów, którzy wykreowaną przestrzeń pogranicza podzielają lub jej nie podzielają. Co zatem dzieje się z odbiorem spektaklu, którego publiczność wywodzi się z innej kultury niż jego twórcy? Jaką pełni funkcję, jeśli artystyczne kryteria jego oceny są albo czysto przypadkowe, albo przeznaczone dla zupełnie innego kontekstu? I w końcu: w czym objawia się ich wartość, przy tak chwiejnych kryteriach i braku jednoznacznej przynależności kulturowej? Postaram się ustosunkować do tych pytań, omawiając wspomniane powyżej przykłady.

The Polish Play została napisana i wyreżyserowana przez Gavina Stride'a i jest przeznaczona do wystawiania w wiejskich świetlicach (village halls). Wykorzystując Pirandellowski motyw metateatru, którego kwintesencję

7 Informacje na temat obsady i pełnego autorstwa tekstu w: N. Werenowska Tu i Teraz ('Here and Now'), Playdead Press, 2013

8 Informacja pochodziz notatki prasowej dotyczącej spektaklu. Zob. https://molodyiteatr.wordpress.com/ (15.09.2015).

9 Pragnę podziękować Joannie Kosmalskiej, Agnieszce Bresler, Robertowi Przekwasowi, Katarzynie (Kasi) Kokowskiej, Gavinowi Stride'owi, Nicoli Werenowskiej i Uilleamowi Blackerowi za pomoc w zbieraniu materiałów oraz udostępnienie tekstów i nagrań, bez których ten artykuł nigdy by nie powstał. 
znajdujemy w sztuce Sześć postaci w poszukiwaniu autora, Stride miesza rzeczywistość z fikcją teatralną w sposób tak efektywny, że przez pierwsze minuty przedstawienia trudno się zorientować, czy przybysz rozpytujący widownię o polską sztukę, która ma być tu gdzieś wystawiana, jest ekscentrycznym widzem czy też postacią sceniczną. Sztuka sama w sobie jest bardziej happeningiem/lokalnym wydarzeniem niż przedstawieniem sensu stricto, ponieważ wprowadza do świata małej wiejskiej społeczności dwóch przybyszów z obcym akcentem: ojca zatroskanego o losy córki (którego rolę gra Michael Strobel) oraz córkę Martę, w której postać wciela się polska aktorka Agnieszka Kożuszek. Marta przyjeżdża do Anglii, by podjąć pracę opiekunki do dziecka. Jej naiwność, skontrastowana z życiowym doświadczeniem ojca, staje się swoistym testem na empatię widzów, a tym samym społeczności przyjmującej obcych przybyszów. Przysłuchując się rozmowie Stanislawa (sic!) i Marty, widzowie poznają prawdziwe intencje i lęki, ale teź i marzenia emigrantów o szczęśliwszym życiu. Sztuka jest wzajemnym oswajaniem obcości, operującej na różnych poziomach. Jest też próbą oddemonizowania prasowej i codziennej oraz anegdotycznej retoryki, dotyczącej nasilonej fali emigracji po roku 2004 ('przyjeżdzają tylko po kasę, zabierają nam pracę i zasiłki, pasożytują na nas').

Celem sztuki jest przewartościowanie myślenia tego typu, jako że człowiek jest tu człowiekowi pomocą, a nie willkiem. Stride zdaje się przekonywać, że wszyscy jesteśmy przede wszystkim „ziemcami"10 , ponieważ zamieszkujemy tę samą planetę, oraz ludźmi, bo należymy do homo sapiens, a dopiero potem jesteśmy członkami narodów i grup etnicznych. Jest to niezwykła w swym podejściu sztuka, bo choć napisana przez Brytyjczyka, nie powiela klasycznego scenariusza, kończącego się powrotem emigranta do swojego kraju". Wręcz przeciwnie, wprowadza postać, która wnosi witalność i pozytywną energię. Taki scenariusz (choć trudno mu odmówić myślenia życzeniowego) zmienia percepcję, ponieważ pokazuje zaufanie wobec Brytyjczyków i przyjmuje ich gościność jako naturalą cechę, niepodlegającą wątpliwościom. Nikt tu nikogo o nic nie oskarża. Improwizacja aktorów i widowni wpisana jest w scenariusz, którego koniec staje się początkiem

Sformułowania tego użył Bogdan Czaykowski w rozmowie z Adamem Czerniawskim (O poezji, nostalgii, krytykach i kryteriach rozmawiaja Bogdan Czaykowski i Adam Czerniawski, red. M. Rabizo-Birek, Polski Fundusz Wydawniczy w Kanadzie-Stowarzyszenie Literacko-Artystyczne "Fraza", Toronto-Rzeszów 2006, s. 148).

11 Taki schemat fabularny ilustruje powieść The Road Home (2007) autorstwa Rose Tremain. 
wspólnej biesiady, momentem wzajemnego zaciekawienia i zbliżenia. Aktorzy zachęcają widownię do rozmowy, burzą s sceniczną fikcję i zmieniając ją w rzeczywistość.

W ocenie aktora grającego polskiego ojca The Polish Play to 'niezwykle oryginalne, odważne i innowacyjne przeplatanie kultur'. Autentyczność tego gestu przypieczętowuje polskie pochodzenie aktorki. Koźuszek jako emigrantka często po spektaklu opowiada swoją 'prawdziwą historię'. W relacji Sarah Redhead, cytującej Strobla, ,kiedy kończymy sztukę, ludzie nie wychodzą, ale zostają i rozmawiają. Nasz spektakl skłania do refleksji, pogłębionej dzięki sytuacji"12. W ocenie Gavina Stride'a ,jednym z największych atutów objazdowego teatru wiejskiego jest scalanie lokalnej społeczności, poniewaź przedstawienia nie są adresowane do koneserów sztuki, ale do każdego. Pisząc The Polish Play, wyraźnie kierowałem się tą myślą i może dlatego spektakl skłania ludzi do mówienia i słuchania, ale nie do stuchania nas, lecz siebie nawzajem, co - jak myślę - pozwala dowiedzieć się lepiej, kim jesteśmy"13.

Wielkim atutem scenariusza jest znakomita rola kobieca, której reżyser powierzył zadanie mediatorki między językami i kulturami, dając jej pełną dowolność w używaniu polskich słów wszędzie tam, gdzie można wzmocnić autentyczność przekazu, wiarygodność postaci czy teź komizm sytuacyjny. Prawie wszystkie kwestie Marty, pochodzące z offu, mają być - według scenariusza sztuki - 'po polsku' i ma to być tekst improwizowany przez aktorkę. Stale obecny humor tej sztuki przenika bariery kulturowe, a w tym konkretnym przypadku dodaje kobiecej postaci siły i odwagi. Sukces tego spektaklu świadczy także o tym, jak ważne są role pisane z myślą o dwujęzycznych aktorkach, wykorzystujące ich emigracyjne doświadczenie i mowę z akcentem, jako cechy naznaczone silną wartością dodatnią.

The Polish Play, choć pisana z myślą o lokalnej publiczności brytyjskiej, wpasowuje się w przestrzeń spotkania dwóch kultur i języków, przez co pozwala lepiej zrozumieć sytuację 'Innego', drugiego człowieka, odmiennej społeczności lub grupy etnicznej. Tworzenie transkulturowej przestrzeni w odniesieniu do środowiska wiejskiego, które z reguły jest pomijane w analizach zarówno społeczno-politycznych, jak i literackich, jest kolejnym

S. Readhead The Polish Playreview, "The List" 24 April 2008, https://www.list.co.uk/article/7914-the-polish-play/ (30.08.2015). Zob. też D. Cavendish The Polish Play: such a sweet shambles, "The Telegraph" 6 February 2008, http://www.telegraph.co.uk/culture/theatre/drama/3670988/ The-Polish-Play-Such-a-sweet-shambles.html (30.08.2015). 
ważnym atutem tego spektaklu/wydarzenia, którego wagę trudno przecenić. Dopełnia go zaufanie, jakim Stride obdarza polską aktorkę, dzieląc z nią improwizowane części tekstu. Doniosłość takiego gestu dostrzegła Eva Ulrike Pirker, omawiając podobny dramaturgiczny chwyt Mike'a Phillipsa w sztuce emigracyjnej You Think You Know Me but You Don't z innego kontekstu kulturowego:

Ów proces przywłaszczenia to bardzo istotne działanie wychodzące poza scenariusz napisany przez autora z Europy Zachodniej nie tylko dla podmiotu ze Wschodu, ale również na temat tego podmiotu. Gra polegająca na dawaniu i otrzymywaniu, na wymyślaniu i odgrywaniu roli „innego” oraz przywłaszczaniu go sobie tworzy sugestywny podtekst ukrywający się za podstawowym poziomem akcji dramatu. ${ }^{14}$

Dwujęzyczność i transkulturowość tej wyjątkowej sztuki jest wyzwaniem dla negatywnej retoryki prasowej, bezustannie definiującej emigrację jako 'problem'. Chociaż z założenia sztuka była adresowana do wiejskiej publiczności, skłonna jestem sądzić, że jej siła oddziaływania w środowiskach miejskich nie byłaby wcale mniejsza.

Przykładem zdecydowanie miejskiego teatru jest historia polskiej grupy Gappad, która dostarcza nieco odmiennego materiału do przemyśleń na temat scenicznej dwujęzyczności z (polskim) akcentem. Jej działalność ujmuje niezwykłym zaangażowaniem i wytrwałością, nie tylko w uprawianiu elitarnej formy teatru, ale także w forsowaniu teatralnej tradycji obcej kulturze docelowej. Znaczącym nurtem w historii polskich osiągnięć scenicznych jest bowiem wizja teatru fizycznego, biomechanicznego, operującego przede wszystkim ciałem, ruchem, symbolem, światłem, dźwiękiem i muzyką. Jest to tradycja wywodząca się głównie z praktyk teatralnych Jerzego Grotowskiego, ale nie tylko im jest przypisana. Słowo, w tak rozumianym teatrze, jest jedynie dopełnieniem lub kierunkowskazem, i to częściej wtórnym. Chociaż przedstawienia teatru fizycznego wychodzą od tekstu dramatycznego, jak było w przypadku takich spektakli jak Hear Me (2009), Jordan (2010), Family Voices (2010), to traktują go bardzo swobodnie, dopasowując wybrane fragmenty do całokształtu wizji scenicznej. Trudno więc o wyraźniejsze zderzenie między teatrem brytyjskim (włącznie z jego szkocką odmianą), w którym

14

E.U. Pirker You Think You Know Me But You Don't - An Introduction, w: Facing the East in The West, ed. B. Korte, E.U. Pirker, S. Helff, Rodopi, Amsterdam-New York 2010, s 164. 
dominuje przede wszystkim słowo, a fizycznym teatrem macierzystej kultury twórców Gappadu.

Nie ulega wątpliwości, że z owym wyzwaniem, wynikającym ze zderzenia dwóch odrębnych tradycji, Gappad radził sobie przez sześć lat swojego istnienia w sposób godny najwyższego podziwu. Grupa nie była nigdy zespołem z etatami i gaźami, a fundusze na wynajęcie sali do prób i spotkań pochodziły z lokalnych grantów, o które jej członkowie musieli starać się sami. Nie mieli agentów ani całej infrastruktury czuwającej nad ich karierą, byli sobie sami sterem, żaglem i okrętem, uosabiając niejako ideał teatru Juliusza Osterwy, z tą wyrá́ną różnicą, że Osterwa nie przewidywał pracy zespołu w obcym kontekście kulturowym. W naszej rozmowie z roku 2015 były dyrektor artystyczny, Robert Przekwas, wspominat:

Wszystko zaczęła Agnieszka [Bresler], a ja dołączyłem do zespołu rok później. Byliśmy po prostu grupą młodych ludzi w obcym kraju, którym do życiowego spełnienia brakowało teatru i kontaktu z kulturą. Każdy z nas przyjechał tu po roku 2004 i pracował zarobkowo, więc teatr spełniał też rolę grupy społeczno-towarzyskiej. Najwyraźniej coś nas wszystkich dręczyło, i chyba w dużym stopniu chodziło o przepracowanie tego, co nas nurtowało. No i właśnie tak się to zaczęło. ${ }^{15}$

Pierwszy spektakl RE-ID [RE-IDENTIFICATION, RE-IDENTYFIKACJA] powstał w ciągu sześciu miesięcy, we współpracy z młodą szkocką reżyserką Kat Harrison, która rok wcześniej ukończyła studia, i polskim kompozytorem Krzysztofem Mielczarkiem. Wzięli w nim udział: Agnieszka Bresler, Pola Brejter, Piotr Kurjata, Dominik Dąbek, Anita Eenyk i Małgorzata Zbudniewek. Po premierze w Tron Theatre w Glasgow w 2007 roku, Gappad wystawił go także na festiwalu Edinburgh Fringe oraz na Govan International Festival. Kanwą przedstawienia było kluczowe pytanie tożsamościowe: jak zmieniam się ja, kiedy zmieniam swój dom? Podstawą scenariusza stały się fragmenty rozmów, listów i głosy polskich emigrantów w wersji dwujęzycznej, mające unaocznić widzom główny dylemat imigranta: powrót czy reidentyfikacja? Ciekawe jest tu nastawienie twórców na ich samych, na traktowanie teatru jako formy służącej przede wszystkim im, a dopiero potem publiczności. Komentując decyzję o utrzymaniu dwujęzyczności

15 Wszystkie cytaty pochodzą z rozmowy autoryzowanej przez Roberta Przekwasa - E.G. 
scenariusza $R E-I D$, Bresler, będąca wówczas dyrektorem artystycznym grupy, wyjaśniała:

Od początku chciałam przygotować przedstawienie, które będzie miało jednocześnie charakter angielski i polski. Wyobrażałam sobie Szkotów siedzących na widowni obok Polaków, chciałam, aby każdy z nich tak samo rozumiał sztukę. Jeśli będą się denerwować, że przez 30 sekund nic nie rozumieją, to tym lepiej, przecież właśnie na tym polega uczucie towarzyszące doświadczeniom migracyjnym. ${ }^{16}$

Dwujęzyczność tekstu o bardzo fragmentarycznym, alinearnym charakterze została również wykorzystana w spektaklu As YouAlways Do [Jak to zawsze czynicie] (2008) ${ }^{17}$, którego tytuł może być odebrany jako przewrotna trawestacja Szekspirowskiego As You Like It (Jakwam się podoba). Przedstawienie o mrocznych i bolesnych motywach nawiązuje do morderstwa Angeliki Kluk, popełnionego w Glasgow przez Petera Tobina. Kiedy znaleziono ciało Angeliki, zamurowane pod kościelną podłogą, w lokalnych mediach mnożyły się najdziwniejsze sensacje o życiu zamordowanej. Tytuł spektaklu jest niejako formą oskarżenia wobec biernego przyzwolenia czytelników na doniesienia prasowe oparte często na domysłach przypadkowych osób. Można go także odczytać jako oskarżenie o współudział w tworzeniu owych narracji. Słyszymy historie zaginionych ludzi w różnych częściach świata, ponieważ spektakl - choć bez nich - jest próbą ujęcia się za nimi, a główny obraz sceniczny to przedstawiony za pomocą swoistej choreografii i ruchu stan osaczenia, zakrzyczenia i w końcu unicestwienia ofiary. Ten symboliczny przekaz nie okazał się jednak dla recenzentów wystarczająco jasny. Spektaklowi zarzucono 'brak narracyjnej klarowności, dezorientacyjną poetykę obrazu i ogólny zamęt, wynikający z braku jasnego przedstawienia kontekstu'. A zatem, paradoksalnie, zarzucono twórcom to, czego przyjęta przez Gappad konwencja teatralna z założenia mieć nie mogła. Doceniono jednak grę aktorską, układ

16 Rozmowa z Agnieszką Bresler, cytowana w recenzji M. Fisher Dramatic Escape from No-Man's Land, "The Scotsman" 27 May 2007, zob. http://www.scotsman.com/news/dramatic-escape-from-no-man-s-land-1-1419655 (30.08,2015).

17 Spektakl miał premierę w Tron Theatre w Glasgow w maju 2008 roku, w czerwcu został pokazany w Edynburgu, w ramach Leith Festival, a w październiku na Festiwalu Teatrów Zależnych w Poznaniu. Brali w nim udział Agnieszka Bresler, Dominik Dąbek, Piotr Kurjata i Anna Nierobisz. Polski tytuł jest moim tłumaczeniem dla czytelnika, nie był wykorzystywany w żadnych materiałach promocyjnych tego spektaklu w Szkocji. 
choreograficzny oraz przejmującą ekspresję obrazu i wyrażono nadzieję, że dalsze dokonania grupy 'ożywią teatralną Szkocję ${ }^{\text {'18 }}$.

Trudno wyrokować, na ile decyzje o trzech kolejnych spektaklach były częściowo odpowiedzią na przytoczone powyżej głosy krytyczne, a na ile naturalnym kierunkiem artystycznego rozwoju grupy. Zarówno w Hear Me, Family Voices, jak i Jordan - w przeciwieństwie do poprzednich spektakli - wykorzystano istniejące teksty dramatyczne, nie wykorzystano w wizji teatralnej scenopisów opracowanych przez uczestników grupy. Nie znaczy to jednak, że były narracyjnie klarowne, o co tak bardzo zabiegali lokalni recenzenci. W pierwszym przypadku kanwą spektaklu był dramat Tadeusza Różewicza Swiadkowie albo nasza mata stabilizacja, w drugim słynna sztuka Harolda Pintera o tym samym tytule, co spektakl Family Voices, a w ostatnim sztuka pt. Jordan, której autorkami są Moira Buffini i Anna Reynolds ${ }^{19}$. Jordan to sztuka-wyznanie matki-morderczyni, oparte na prawdziwej historii i napisane przez obie autorki po wyjściu z więzienia, gdzie się poznały i nawiązały przyjaźńn ${ }^{20}$.

Zarówno Family Voices, w reżyserii Iwony Głowińskiej, jak i spektakl Jordan w reżyserii Roberta Przekwasa, były wystawiane wyłącznie w języku angielskim, ale z akcentem, który nadawał zupełnie inny wymiar obu sztukom²1. Truizmem jest stwierdzenie, że sceniczny język staje się symbolem we wszystkich swoich aspektach, a fakt, że brytyjska kultura ma do akcentu stosunek absolutnie wyjątkowy, traktując go jako wyznacznik toźsamości, pochodzenia i statusu społecznego, tym bardziej nie pozwala tego wymiaru pominąć. Kierując się polityczną poprawnością, można udawać, że akcentu nie dostrzegamy (i tak teź zareagowali lokalni recenzenci), ale trudno założyć, że wszyscy widzowie odebrali spektakl zgodnie z zasadą politycznej poprawności22. Kwestia ta wydaje mi się o tyle ważna, że wymowa z obcym akcentem (przez zaistnienie na narodowych scenach szkockiego teatru) upomniała się o społeczne równouprawnienie języka, poszerzając lokalną przestrzeń

18 Zob. I. McMillan Hear Me, "The Scotsman" 8 May 2009 https://joycemcmillan.wordpress. com/2009/05/08/hear-me/ (10.10.2015).

19 Po raz pierwszy sztuka była wystawiona przez Lilian Baylis Theatre w Londynie w 1992 roku.

20 W ciągu dwóch miesięcy sztuka była grana od 11 do 15 maja 2010, w Tron Theatre w Glasgow, i 19 czerwca w Roxy Art House w Edynburgu, i zebrała wiele pochwał.

21 Spektakl Family Voices miał swoją jednorazową polsko-angielską wersję, przygotowaną specjalnie na Festiwal Teatrów Zależnych w Poznaniu w 2010 roku.

22 O tym, że tak nie było, przekonały mnie uwagi widzów zasłyszane po dwujęzycznym spektaklu HearMe. 
o nowy, transkulturowy wymiar. Jej obecność w teatrze niejako usankcjonowała emigracyjność - zarówno kultury, jak i życia - przybliżając czy nawet narzucając go Szkocji w naoczny, przekonujący sposób. W tym artystycznym geście zawiera się nieoceniona wręcz wartość działalności Gappadu, bez względu na to, czy grupa ta miała tego świadomośćc ${ }^{23}$.

Kiedy Magdalena Kaleta przyjęła wyzwanie, by zagrać główną rolę w spektaklu Jordan, miała na swoim koncie rolę w sztuce 'e Polish Quine, okrzykniętą sukcesem ${ }^{24}$. Wcieliwszy się w postać Polki przybyłej do Wielkiej Brytanii po II wojnie światowej, odzyskała porzucone wcześniej życie zawodowe, co z kolei pomogło jej podjąć decyzję o pozostaniu w Szkocji i kontynuowaniu kariery aktorskiej ${ }^{25}$. W pozytywnych w tonie recenzjach ze spektaklu Jordan nie obyło się jednak bez nawiązania do stylu reżyserii Przekwasa, który określono jako 'wycyzelowany, surowy, specyficzny i przypisano go (o ironio!) polskiemu pochodzeniu aktora-reżysera ${ }^{26}$. O ile tekst sztuki Jordan trochę skrócono, z oryginalnego dramatu Różewicza weszła do przedstawienia Hear Me zaledwie jedna trzecia utworu: dialog Kobiety i Mężczyzny oraz poemat otwierający Świadków. Motywem przewodnim jest tu brak porozumienia, kiedy wykracza ono poza język werbalny lub kiedy - paradoksalnie - język werbalny bardziej utrudnia, niż wspiera komunikację. Decyzja o rezygnacji z dwujęzyczności i wystawieniu sztuki w języku angielskim wyraźnie wskazuje na pozawerbalny, filozoficzny aspekt ogólnoludzkiej komunikacji. Wspiera ją także określony sposób gry aktorskiej, sceniczny ruch, symboliczny język ciała, światło, dźwięk i muzyka Krzysztofa Mielczarka. Refleksja nad tym, jak dotrzeć do drugiego - pozornie najbliższego nam - człowieka, pokonując różnice płci, odmienność poglądów społecznych czy też postaw filozoficznych, staje się głównym przekazem tego przedstawienia. Hear Me zdaje się potwierdzać przekonanie grupy, że wartość prawdziwie artystycznych dokonań sytuuje się poza politycznym wymiarem rzeczywistości, którą

23 O równouprawnieniu akcentowanej mowy w kontekście społecznym wnikliwie pisze bell hooks, analizując je w odniesieniu do doświadczeń amerykańskich. Zob, rozdział pt. Language. Teaching New Worlds/New Words z jej książki Teaching to Transgress, Routledge, New York-London, 1994 , s. 167-175.

M. Zajac Dogstar Theatre Company ",The Scotsman" 25 May 2007, http://www.scotsman.com/ news/polished-production-1-748941\#axzz30ohiBIWI (10.09.2015). Zob. tamże. 
najbezpieczniej zignorować. Ironia życia wyraźnie jednak temu podejściu zaprzecza: ewidentna zmowa prasowego milczenia wokół akcentu aktorów już sama w sobie stanowi polityczny komentarz do ich gry.

O tym, jak ważne były kwestie komunikacji dla całokształtu artystycznych dokonań grupy, nie tylko dla omawianego powyżej przedstawienia, potwierdzają uwagi Roberta Przekwasa ze wspomnianej wcześniej rozmowy:

Kierowała nami przede wszystkim potrzeba wzajemnego porozumienia. Jako emigranci byliśmy dość wyizolowani, teatr dawał możliwość przerwania tej izolacji. Dodawał nam też odwagi do artystycznego zaistnienia i poszukiwania siebie w innym kulturowym kontekście. Tej odwagi często sami sobie też dodawaliśmy.

Nasza wizja teatru była oparta na potrzebie kontaktu, otworzenia się i wzajemnego poznania: aktorów między sobą oraz aktorów z widzami. Brytyjscy krytycy wpisali nas w tradycję Grotowskiego, ale przecież Grotowski nie ma monopolu na teatr fizyczny, bo dla wielu innych teatralnych twórców najważniejsza była komunikacja między aktorem i widzem, a tekst często jest tylko pretekstem do nawiązania tego kontaktu (dość ws pomnieć polskich brutalistów).

Otwarcie na drugiego człowieka, będące podstawą aktorskiego przesłania w teatralnej wizji Gappadu, znalazło też swoje odbicie w organizowaniu różnorodnych warsztatów, adresowanych nie tylko do aktorów, ale też do lokalnej społeczności i do polskich dzieci ${ }^{\mathbf{2 7}}$. Prace warsztatowe i teatralne grupy wspierane były przez gościnne wizyty innych aktorów, np. Sławka Gostańskiego z Teatru Węgajty (mieszkającego od kilku lat w Szkocji) czy też Magdaleny Mróz z Teatru Ciałonośnego. Oprócz Polaków współpracowali z Gappadem również Roberta Secchi i Raul Laiza z Teatro La Madrugada (Włochy), David W W Johnstone z Lazzi Experimental Arts, Antonia Doggett oraz Bill Wright.

Hear Me, jako trzeci spektakl przygotowany przez tę samą grupę, przyniósł ciekawe obserwacje dotyczące kierunku jej artystycznych poszukiwań. Pisząc o nim, Joyce McMillan, tak podsumowuje dotychczasowe wysiłki:

27 Warsztaty pt. HUNGER (2012) poprowadził w Glasgow Robert Przekwas, a warsztaty dla dzieci pt. Diabły nie z tej ziemi (wspólny projekt Gappadu i Polish Cultural Festival) odbyły się 3 grudnia 2011 roku w Edynburgu z udziałem R. Przekwasa i D. Dąbka. Pomysłodawczynią, reżyserką i autorką scenariusza była Iwona Głowińska-Denton. 
Widzimy aktorów pokonujących kolejne etapy pracy nad sobą ale bez poczucia rzucenia wszystkiego na szalę przedstawienia, które świat ma za wszelką cenę zobaczyć. [...] Być może ów stan 'bycia w procesie tworzenia i dążenia do czegoś' nie powinien nas dziwić? Zwłaszcza kiedy zdamy sobie sprawę, że zespół istnieje w przestrzeni pogranicza dwóch kultur i że przestrzeń tę ciągle przepracowuje. ${ }^{28}$

Uwagi recenzentki dotyczące etapu Gappadu jako 'etapu teatralnych etiud', 'wprawek aktorsko-scenicznych', które przygotowują grunt pod mniej ‘prowizoryczne przedstawienie', wydają się znaczące dlatego, że określają lokalne oczekiwania. Ogólny ton recenzji jest bardzo pozytywny i wynika z niej jasno, że Joyce McMillan docenia talent, zapał i grę aktorską. Komentując wcześniej kreację Bresler w As You Always Do, podkreśla jej 'doskonałą sceniczną wyrazistość' i zaznacza, że aktorka 'potrafi zmieniać wyrażone przez nią postaci tak jasno jak kameleon kolory'. Jednak recenzję sztuki opartej na tekście Różewicza kończy stwierdzeniem, że 'Gappad nadal szuka projektu, który zapewniłby mu trwałe miejsce w teatralnym sercu Szkocji'29.

Hear me wiąże się tematycznie z Family voices, jako że obie szukają wzajemnego porozumienia, mają na celu zilustrowanie tajemniczych i często paradoksalnych mechanizmów ludzkiej komunikacji lub jej braku. Pamięć i rozpamiętywanie tego, co bezpowrotnie minęło, co jest i co może się zdarzyć, to także wspólny motyw obu sztuk. Ponieważ dramat Pintera był wystawiony w języku angielskim i nie dotyczył tematu emigracji, w recenzjach doszedł do głosu kulturowy rozdźwięk przy omawianiu podejścia do tekstu. Recenzenta najbardziej zaskakuje fakt, że 'ekspresywność obrazu zagłusza tekst' ${ }^{\prime 30}$. Mamy tu zatem po raz kolejny do czynienia z zarzutem postawionym na róźnicy kulturowego odczytania zaproponowanej przez Gappad konwencji, a więc zakwestionowanie innego podejścia do tekstu, które nie spełniło oczekiwań krytyka, ukształtowanych przez długoletnią lokalną tradycję.

Spektaklem wieńczącym dorobek artystyczny Gappadu była sztuka Spina/ Backbone, ponownie nawiązująca do motywu emigracji i konwencji z RE-ID. Tytuł Spina to symboliczne stopienie dwóch języków: rdzenia angielskiego

28 Zob. J. McMillan HearMe.

29 Tamże.

30 Recenzja z Family voices "The Scotsman", 21 June 2010, http:/www.scotsman.com/news/ theatre-reviews-family-voices-the-old-lady-the-umbilical-cord-1-813917\#axzz3oohiBIW| (10.09.2015). 
słowa 'spine’ i polskiej końcówki ‘-a'. Inspiracją do spektaklu był jednostronicowy tekst napisany w języku polskim przez Katarzynę (Kasię) Kokowską i przetłumaczony na angielski przez Gappad. Powraca tu motyw imigracyjnego doświadczenia, które zdaje się bardziej obciążać niż uskrzydlać. Przedstawienie jest niejako domknięciem działań teatralnych, świadomie posługującym się martyrologiczno-cierpiętniczą symboliką, która zyskuje tu swój pełny wyraz. Podkreśla ją wykorzystanie dwóch języków, a także dźwięki w tle, na które składa się gra na akordeonie, polska modlitwa i słowiańska piosenka ludowa. Są tu wiele sugerujące motywy, jak np. biała maska aktorki (A. Bresler), która w jednej scenie zmienia jej twarz, a w innej jest miseczką do jej obmywania. Postać w tle (R. Przekwas), owinięta od pasa w białe sukno, ilustruje cierpiętnicze doznania, zmagania z niewidzialnymi, acz fizycznie odczuwanymi koszmarami, lękami i natręctwami. Postać z lewej strony sceny to leżący pod ciężarem krzyża i usiłujący co rusz powstać człowiek (P. Kurjata), uosabiający jednocześnie ludzki los i męki Chrystusowe ${ }^{31}$. Sztuka nie miała szerokiego zasięgu, pokazywana była w kameralnych salach dla ograniczonego grona publiczności, więc spektakl nie był recenzowany w prasie w takim stopniu, jak wcześniejsze przedstawienia.

W roku 2012 Robert Przekwas podjął decyzję o zakończeniu działalności Gappadu. Wielu uczestników grupy wróciło do Polski, inni odnaleźli się w odmiennych, czasem pokrewnych zawodach. Agnieszka Bresler prowadzi parateatralną działalność z grupami ludzi społecznie wykluczonych i trudno nie dostrzec tu paraleli między jej doświadczeniem emigracyjnym, które przynosi silne poczucie wyobcowania czy nawet wykluczenia, a obecną działalnością. Kiedy w czasie rozmowy z Robertem Przekwasem zapytałam, dlaczego wśród uczestników organizowanych przez niego warsztatów była tak mała liczba Szkotów i Brytyjczyków, za to (oprócz Polaków) przeważali przedstawiciele innych grup etnicznych, odpowiedział, że nie zastanawiał się nad tym specjalnie, ale dodał po chwili: 'Może dlatego, że było nam łatwiej komunikować się z tymi, którzy byli w podobnej sytuacji. Im było też łatwiej porozumieć się z nami. Może dotarcie do Szkotów było dla nas na tamtym etapie zbyt trudne? Może to my nie chcieliśmy tego trudu podjąć? Nie wiem'.

Gappad był kreatywną formą zaistnienia w nowym świecie, scalał środowisko artystyczne i wzmacniał w uczestniczących w tej przygodzie Polakach poczucie własnej wartości. To, że ich eksperymentalne przedstawienia były

31 Krótsza, pięciominutowa wersja spektaklu jest dostępna na Youtube. Zob. https://youtu.bel rJLrz-TWy3Q (10.09.2015). 
pokazywane na scenach profesjonalnych teatrów, spowodowało, że pomogły one usankcjonować obecność polskiej kultury, języka i mowy z akcentem w świecie, w którym hegemoniczna rola angielskiego wcale nie maleje, ale wręcz wzrasta ${ }^{32}$. Artystyczną wartość dokonań grupy trudno jednoznacznie ocenić, ale wydaje mi się, że nie ma to specjalnego znaczenia, zwłaszcza w świetle tego, jak ważną, wręcz bezcenną rolę Gappad odegrał w środowisku polonijnym i emigracyjnym Szkocji. Uczestnicy grupy napisali fascynujący rozdział transkulturowego teatru, przełamując społeczną i kulturową izolację. Ilustrując dylematy emigracyjne i tożsamościowe, wprowadzili to zagadnienie do szerszego obiegu społecznego, upominając się o równość w traktowaniu ich samych. Pokazali, że polscy emigranci nie wymagają specjalnej troski, że nie są ubogimi krewnymi, a pełnoprawnymi rezydentami. Widzę w tym unikalną, nieocenioną, a także niedocenioną wartość ich scenicznych i pozascenicznych dokonań.

Tu i Teraz ('Here and Now') - jak wskazuje juz sam zapis oryginalnego tytułu - jest sztuką dwujęzyczną, napisaną głównie, choć nie wyłącznie, przez Nicolę Werenowską. Zwraca tu uwagę bardzo realistyczne podejście do języka, jego struktury i akcentu. Wszystkie elementy językowe są skrupulatnie wykorzystane do zarysowania psychologicznego portretu postaci. Sztuka jest utrzymana w konwencji realistycznej i przedstawia samotną matkę (Marysię), wychowującą 16-letniego syna (Kubę) i dążącą do jego całkowitej asymilacji z angielskim środowiskiem.

Kategoria polskości jest tu mocno skomplikowana i wyraźnie zabarwiona transkulturowym kontekstem. Nie ma jednoznacznych nacechowań, ponieważ polskość jest po trosze utożsamiana zarówno ze źródłem cierpień (przemoc ojca), jak i miłych doznań (czułość i opiekuńczość wobec Kuby). Marysia uosabia bolesną złożoność swej polskości: z jednej strony wykorzenia ją ze swojego życia, a z drugiej sekretnie jej pragnie. Jej łamana angielszczyzna, którą uparcie się posługuje, robiąc cały czas te same (a czasem nowe) błędy, staje się metaforą jej dwubiegunowego życia. Obcego akcentu nie da się ukryć. Marysia może udawać, że go nie ma, ale dla wszystkich innych osób

Świadczą o tym chociażby nieustające od 10 lat wysiłki środowiska polonijnego o wprowadzenie języka polskiego jako obcego do szkockich szkół. W ubiegłym roku ogłoszono planowaną na 2018 rok likwidację języka polskiego (A Levels) w Anglii. Philip Oltermann, komentujący ten fakt w dzienniku "The Guardian", zauważył, że 'ta zaskakująco nieprzemyślana decyzja czyni z Wielkiej Brytanii swoisty dziwoląg: „kraj wielokulturowy, który jawi się jako monoglota”. Zob. In Praise of.... The Polish Language, "The Guardian” 6 March 2015, http://www.theguardian.com/ commentisfree/2015/mar/o6/polish-language-britain-exam-board-a-level (10.09.2015). 
jest on jak widoczne - czy raczej słyszalne - znamię. Angielski Kuby jest bezbłędny, od czasu do czasu to on właśnie koryguje angielskie wyrażenia matki, a ona chwali się przed nim wyuczonymi w pracy nowymi słówkami, jak np. 'appraisal'. Ta swoista językowa symbioza de facto bardziej ich zbliża, niż dzieli, i chociaż Marysia nie dopuszcza do siebie tej myśli, to właśnie dwukulturowość Kuby, któremu grozi monojęzyczność, może okazać się dla jego przyszłości lepsza niż bezbłędny angielski.

Sztuka Werenowskiej to bogaty materiał do rozważań o stygmacie emigranta. Stygmacie społecznym, językowym, kulturowym czy wreszcie rodzinnym. Pokazuje głęboką złożoność tych zagadnień i uświadamia, że nie ma rozwiązań idealnych, że każde wiąże się z jakąś ceną i stratą, że paradoksalnie może zarówno osłabić, jak i wzmocnić, że konsekwencje podejmowanych wyborów są nieprzewidywalne. Co więcej, wybory, które wydają się w danym momencie gwarancją sukcesu, nie zapewniają go w przyszłości. To, co uchodzi za słuszne i poprawne w jednej kulturze, jest nacechowane odwrotnie w drugiej. Życie imigranta jest więc bezustannym szukaniem swoistego kulturowego modus vivendi, niekończącym się procesem tworzenia nowego życiowego idiomu na zaistnienie, próbą pogodzenia wartości, które często są nie-do-pogodzenia. Sztuka Werenowskiej wnikliwie ilustruje te dylematy.

W poglądach Marysi wyraźnie nie ma miejsca na przekonanie, że to właśnie dwujęzyczność zwięlksza szanse na rynku pracy, ułatwia nawiązanie międzynarodowych kontaktów, daje większą możliwość wyboru, nie mówiąc już o kulturowym i intelektualnym bogactwie. Jej wizja Polski jest silnie negatywnie nacechowana, co - ciekawe - nie jest znamienne dla całej generacji: jej młodsza o cztery lata siostra Anna uosabia niezwykle pozytywny wizerunek polskości. Przywiązanie Anny do języka i rodzinnych polskich tradycji może uchodzić za wzór współczesnego apolitycznego patriotyzmu. Anna nie zachłystuje się nieosiągalnym dla przeciętnego człowieka standardem życia, promowanym w kolorowych pismach i prasowych plotkach o celebrytach. Jej londyńskie doświadczenia to walka o przetrwanie za wszelką cenę, wegetacja na granicy ubóstwa i upokarzająca praca, która często idzie w parze z seksualnym wykorzystywaniem.

Tu i Teraz ('Here and Now') napisana jest w obu językach, z polskim tłumaczeniem podanym w nawiasach lub obok głównego tekstu, aby nie wykluczać nikogo, kto zna tylko jeden język. Niewątpliwie chodzi tu o pokazanie pewnej autentyczności doświadczenia i mimetyczne odzwierciedlenie opisywanego świata, ale nie tylko. Namacalną konsekwencją takiej autorskiej decyzji jest 
wspomniane wcześniej stworzenie ról dla dwujęzycznych aktorów, a w rezultacie możliwość pracy dla aktorów imigrantów. Dodatkową zaletą decyzji Werenowskiej - tak jak było w przypadku teatru objazdowego Farnham Maltings i wybranych spektakli Gappadu - jest równoprawne zaistnienie obu języków na jednej scenie. W niektórych scenach polski jest tylko echem, w innych staje się nim angielski. Owa dwujęzyczność odbija paralelną rzeczywistość poza teatrem, ponieważ język polski, według oficjalnych statystyk, jest obecnie drugim powszechnie używanym językiem w Wielkiej Brytanii, choć jeszcze kilka lat temu był nim pendżabski i urdu. Nie ulega wątpliwości, że spora część Brytyjczyków jest wielojęzyczna, i choć angielski dominuje, uwrażliwienie na inne języki i ich doniosłość w pielęgnowaniu kulturowych tradycji różnych grup etnicznych, nabiera coraz większej wagi. Sztuka Werenowskiej podkreśla wagę takiego podejścia i - jak było w omawianych wcześniej przykładach - pomaga przełamać barierę językową, oswaja dwujęzyczność czy też wielojęzyczność, stawiając polski obok angielskiego na a ng ielskiej scenie w sposób sugerujący językowe równouprawnienie. Ten gest wynika także z przekonania, że dwujęzyczność nie zubaża treści ani nie odbiera sztuce głębi. Zadziwia to, że Werenowska, jako autorka sztuki, mówi biegle po niemiecku i francusku, ale nie zna polskiego. Jak się okazuje, jest to język rodzinny jej męża (reprezentującego drugą generację imigrantów), a w napisaniu polskiej części sztuki (będącej tłumaczeniem z angielskiego) pomogli jej przyjaciele, których nazwiska figurują w opublikowanej wersji dramatu ${ }^{33}$.

Ciekawego materiału do przemyśleń dostarcza rozbieżność w ocenie sztuki przez lokalnych recenzentów. Z jednej strony Dominic Cavendish, recenzent gazety „The Telegraph" twiedzi, że 'sztuce brakuje psychologicznej głębi, że wymaga politury, lub gdyby powiedzieć to inaczej zapożyczając język kulinarny, są w niej same kluski bez mięsnej wkładki'. Dodaje, że choć 'miło jest słyszeć polski na scenie, utrudnia to zrozumienie sztuki (sic!), natomiast łamany angielski Marysi (którą grała Ania Sowinski) brzmi bardzo wiarygodnie (rings true) ${ }^{\prime 34}$. Z drugiej strony jednak Daniel Nelson, piszący dla „OneWorld”, wyraża nadzieję na 'więcej tak dobrych sztuk, skoro ostatnie statystyki podają, że liczba Polaków w Brytanii wynosi 545 tysięcy i jest drugą pod względem liczebności grupą etniczną (foreign nationals), jeśli za

\footnotetext{
Są to Anna Elijasz, Paulina Nowak i Ania Śliwa. Zob. N. Werenowska Tu i Teraz ('Here and Now'), Playdead Press, 2013, S. 3. 
kryterium uznamy kraj urodzenia'35. Krytyk mylnie zakłada, że autorka jest Polką, chwali doskonałą grę aktorską i kończy recenzję stwierdzeniem, że 'Werenowska ma talent, a więc miejmy nadzieję, że nadal będzie opowiadać historie'. Opinie te dowodzą, jak chwiejne i zawodne stają się kryteria oceny artystycznej, bo siłą rzeczy oparte są na czysto intuicyjnym oglądzie, subiektywnych odczuciach i niesprawdzonych założeniach. Zastanawia też fakt, dlaczego recenzenci nie przywiązują wagi do roli, jaką tego typu sztuki odgrywają w odniesieniu do profesjonalnej sytuacji aktorów-emigrantów. Dlaczego pomijają ludzki wymiar spektaklu, który wykracza poza sceniczną fikcję? Jest przecież mocno związany z rzeczywistością społeczno-polityczną, którą wspomnieni krytycy dzielą z imigrantami. Odnosi się wrażenie, że ich uwagi mówią więcej o braku empatii współczesnego, z pozoru kosmopolitycznego społeczeństwa, niż o samej sztuce. Przekonują również, że wartość transkulturowego teatru wymyka się złudnym artystycznym kryteriom i że o coś innego tak naprawdę tutaj chodzi.

Innym ciekawym przykładem, zainspirowanym doświadczeniem emigracyjnym, w którym do głosu dochodzi nie tylko dwujęzyczność, ale także wielojęzyczność, jest przedstawienie wykorzystujące konwencję musicalu, burleski i tragikomedii, z tańcem i śpiewem, w opracowaniu ukraińskiego teatru emigracyjnego Molodyi Teatr z Londynu. Przygotowana w odpowiedzi na antyemigracyjną retorykę brytyjskich mediów sztuka nosi tytuł Bloody East Europeans [Przeklecci Wschodnioeuropejczycy] i jest pomyślana jako interaktywna zabawa z udziałem publiczności. Mamy tu stałe teatralne motywy, ale w nowej szacie, z oryginalnymi pomysłami inscenizacyjnymi, ośmieszającymi obie strony: przyjeżdzającą i 'przyjmującą. W tej scenicznej wizji Polacy nagle stali się częścią słowiańskiej rodziny, a ich wyjątkowość jest zredukowana do słów, których nikt nie potrafi wymówić, jak np. Grzegorz Brzęczyszczykiewicz, ponieważ wszystkie odmienne cechy dzielą z innymi siostrzanymi krajami, takimi jak Ukraina, Czechy, Słowacja, Litwa czy też Białoruś. To zestawienie narodowości jest o tyle znaczące, że odzwierciedla przeciętne (brytyjskie) postrzeganie, zgodnie z którym wszystkie kraje słowiańskie stanowią jedność i rozróżnienie poszczególnych nacji jest dla przeciętnego mieszkańca wyspy sporym wyzwaniem ${ }^{36}$. Ogólna 'dezorientacja słowiańska', dotycząca

35 D. Nelson Here and Now: A Story of Poles in Britain on-line: http://www.nicolawerenowska.co.uk/nicolawerenowska.co.uk/Recent_events.html (10.09.2015).

36 Jest to zresztą mechanizm percepcyjny, który działa w obie strony, ponieważ dla przeciętnego Polaka rozróżnienie między Anglią, Szkocją, Walią czy też Irlandią Północną po prostu się nie 
tej części Europy, jest źródłem humoru, co znakomicie oddaje m.in. piosenka ,językowa”, mająca na celu nauczyć publiczność wybranych słów z języka 'wschodnioeuropejskiego':

Aktorzy ustawiają sięjak chór i śpiewają na melodię 'Katiusha':

Zdrastvuite - is Russian for 'hello'

Labadiena - Lithuanian for 'good day'

Tak i Nie - is Polish for 'yes/no',

Dobre je - Ukrainian for 'okay'.

Other words in Eastern European:

Are poka, spasibo and duran,

Multumiri Molia Dobhre Pivo

Vybachaite, jakshcho shchos ne tak. ${ }^{37}$

Swoiste u/językowienie ma tu rangę symboliczną, ponieważ dotyczy zalet wielojęzyczności, traktując prześmiewczo hegemoniczną rolę języka angielskiego. Na scenie są grane i śpiewane popularne utwory rockowe z lat 70., które wyraźnie oźywiają publiczność, ponieważ do znanych melodii napisano zabawne teksty ilustrujące absurdalność wielu sytuacji, zarówno dla Brytyjczyków, jak i dla imigrantów. Otwierająca przedstawienie scena przebudzenia, kiedy to robotnicy w papierowych workach na głowach szykują się do pracy, może być odczytana symbolicznie. Nie jest wykluczone, że w zamiarze twórców spektakl ma działać jak przebudzenie, otwarcie oczu na problemy wokół nas, na dostrzeżenie człowieczeństwa wschodnioeuropejskich przybyszów. Ale bez idealizacji, ponieważ również wśród nich dochodzi do wzajemnego wyzysku, szantażu, wykorzystywania sytuacji tych, którym się nie powiodłodynamika emigracji została zawarta w piosenkach i tańcach z przytupem, szpadlem i słowiańskimi wiankami. Skecze, bufonada i kalambury oparte są na świetnej znajomości krajów słowiańskich. Wszystkie kiczowate rekwizyty i te, które przeciętny Brytyjczyk kojarzy z Europą Wschodnią, są wykorzystane w przedstawieniu, bawią i cieszą widownię, acz nie bez nutki goryczy, powagi i wisielczego humoru.

liczy i w rozmowach potocznych, których byłam w Polsce świadkiem, całe Zjednoczone Królestwo nazywane jest Anglią. 
Oprócz znakomitych pomysłów inscenizacyjnych, powstałych pod kierunkiem Olesyi Khromeychuk, niepodważalnym atutem przedstawienia jest jego błyskotliwy scenariusz. Autor przedstawia się w notce programowej jako Honorary Eastern European i w istocie nim jest. Szkot z urodzenia, Uilleam Blacker, studiował języki wschodnioeuropejskie na Uniwersytecie w Glasgow, Londynie i Oxfordzie i może poszczycić się biegłą znajomością rosyjskiego, ukraińskiego i polskiego. Od roku 2014 jest wykładowcą na University College w Londynie. Teatrem zajął się dzięki swojej partnerce, która prowadzi ukraińską grupę, a on wspiera ich artystyczne wysiłki talentem i zaangażowaniem. W tym spektaklu jest jednym z grających na gitarze i śpiewających aktorów. Spektakl obfituje w akcenty i języki, dodaje odwagi ukraińskim aktorom, którzy tak jak Gappad mierzą się z pograniczem kultur w brytyjskim kontekście, ubiegając się o prawo do zaistnienia i do wzmocnienia by posłużyć się terminem Marthy Nussbaum z innego kontekstu - swojej swoiście 'kosmopolitycznej przynależności'38. Przykład Molodyi Teatr jest o tyle ciekawy, że ilustruje zasadę kulturowego włączenia, a nie wyłączenia, przez to, że sympatyzuje z całym regionem słowiańskim. W swoisty sposób poszerza alfabet kulturowy ${ }^{39}$ i przestrzen 'transkulturowych idiomów', zwracając uwagę na to wszystko, co łączy i dzieli kultury słowiańskie, z kulturą brytyjską jednocześnie.

Przyglądając się powyższym omówieniom trudno nie zauwaźyć, że jedną z głównych wartości omawianych powyżej przedstawień jest wprowadzanie w życie i rozwijanie tego, co coraz częściej nosi miano wyobraźni narracyjnej ${ }^{40}$, a co inni badacze nazywają też wyobraźnią empatyczną ${ }^{41}$. Jest to wyobraźnia,

38 Odwołuję się tutaj do 'paradygmatu umiejętnościowego' (capabilities approach) Marthy Nussbaum. Zob. Creating Capabilities. The Human Development Approach, The Belknap Press of Harvard UP, Cambridge-London 2011.

39 Azade Seyhan, posługując się tym terminem, analizuje diasporyczną literaturę niemiecką (i turecko-niemiecką), jaka powstała w USA. Zob. A. Seyhan Writing Outside the Nation, Princeton University Press, Princeton, NY 2001.

40 Wymieniając zespół 'umiejętności' (capabilities) niezbędnych do pełnego rozwoju ludzkiego potencjału, Mar tha Nussbaum wprowadza kategorię 'zmysły, wyobraźnia i myśl,' do której inni badacze odnoszą się, używając terminu 'wyobraźnia narracyjna'. Zob. M. Nussbaum Creating Capabilities..., s. 33 .

41 Zwrotem tym posługuje się Susan Gubar, przytaczając wcześniej myśl Shelleya: „W Obronie poezij Shelleya wyobraźnia jest traktowana jako mięsień, którego należy ciągle używać. Aby być prawdziwie dobrymi, twierdzi Shelley, ludzie muszą intensywnie ćwiczyć wyobraźnię, utożsamiając się z sytuacją innych w taki sposób, aby to, co boli i sprawia przyjemność innym, 
która ma ułatwić jak najpełniejsze zrozumienie sytuacji drugiego człowieka, która widzom/czytelnikom może być całkowicie obca i nie interesować ich. Nie ulega wątpliwości, że wszystkie omawiane tu spektakle mocno wpisują się w kontekst, w którym powstały i z którego się wywodzą, dlatego tez nie bardzo daje się zastosować w odniesieniu do nich typologię opartą wyłącznie na wyborze języka, narodowości autora, czy też jednoznacznie przypisać je kulturowo, ponieważ każdy jest zjawiskiem pogranicza. Nawet typologia zaproponowana przez Edwarda Balcerzana, uwzględniająca obecność wielu języków w jednym utworze, też nie ułatwia tu opisu, ponieważ uwagi badacza dotyczą utworów konkretnego autora lub autorki w polskiej literaturze, a więc w utworach drukowanych, a nie wygłaszanych na scenie, co znacznie zmienia semantyczny zakres rozważań ${ }^{42}$.

Każdy z omawianych tu spektakli tworzy na swój sposób nowe wartości pogranicza kultur i języków, uczestnicząc jednocześnie w procesie ich powstawania. Wymieszanie językowo-kulturowe nie jest jednak artystycznym celem samym w sobie, ale nawiązuje wyraźnie do wymiaru ludzkiego, tak typowego dla naszych czasów zjawiska mobilności. Dwu(wielo) języczne teksty przedstawień stawiają nie tylko doniosłe pytania, ale także uczą pokory, przywracają godność 'Innych' i uwrażliwiają, ucząc empatii oraz wzajemnego poszanowania i m.in. w tym widzę ich ogromną wartość i wagę. Kto wie, czy nie mamy tu do czynienia z zalążkiem zjawiska o charakterze podobnym do kultury Chicano, powstałej, jak wiadomo, z wymieszania języków i tradycji kultury amerykańskiej, z różnorodną i wielojęzyczną kulturą obszaru meksykańsko-hiszpańskiego. Chicano doczekało się obecnie własnej nazwy i odrębnych studiów. Być może takie właśnie myślenie porównawcze będzie celem rozważań w dalszych badaniach nad tym złożonym i fascynującym zjawiskiem tworzenia się nowej kulturowej przynależności - nieuniknionym rezultatem globalizującego się świata.

stało się udziałem ich samych" ["In Shelley's Defence of Poetry, the imagination is imagined as a muscle that needs to be used. To be 'greatly good,' according to Shelley, people 'must imagine intensely', 'putting themselves in the place of another and of many others' so the 'pains and pleasures of the species become their own']. Zob. S. Gubar Poetry after Auschwitz. Remembering What One Never Knew, Indiana University Press, Bloomington-Indianapolis, 2003, s. 242. 


\section{Abstract}

\section{Elwira M. Grossman}

UNIVERSITY OF GLASGOW

Bi(Multi)Lingual Theatre in the Globalized British Context; or, Different Styles of Migration and Transcultural Drama

Focusing on selected bi(multi)lingual plays recently performed in the UK, the essay deals with the broader theme of intercultural communication and Polish migrants' contribution to the local target culture. Grossman examines the possibility of creating a new transcultural form of theatre as an artistic means of facilitating mutual understanding and intercultural experiences. She suggests replacing the question of artistic merit by the shows'function in reinforcing intercultural dialogue. The performances discussed are shown not only to strengthen the migrants' integration but also to secure their feeling of emotional and cosmopolitan belonging to a globalized world without undermining their sense of human dignity and their belief in social equality.

\section{Keywords}

Polish-Scottish migration theatre in Great Britain, transcultural drama and theatre, bi(multi)lingual theatre, intercultural communication, cosmopolitan cultural belonging 